\title{
Globalisation and New Threats: Terrorism
}

\begin{abstract}
Terrorism is not what could be called a new phenomenon in the world. The end of the Cold War and globalisation, however, "have let the genie out of the bottle". In this article the author analyses issues pertaining to the definition of terrorism, tendencies of the terrorist threat (particularly, causes of the growing fatality of terrorism), the impact of globalisation on the phenomenon of terrorism and opportunities and dangers behind the fight against terrorism in the globalisation age. The article claims that during the age of globalisation terrorism becomes popular not only as a means for an asymmetric fight against the stronger opponent of the world's "evil" states; the fight against terrorism is more and more often used as a supplementary instrument in the external and internal policies of Western world democracies. Devoid of an agreement on what terrorism is, states, facing the pressure of foreign and internal interests and/or external pressure, have become used to exaggerating the appeal of the terrorist threat, which, in turn, creates a counterproductive effect and increases security stakes.
\end{abstract}

\section{Introduction}

As soon as threats become reality, they enter academic, political and practical security agendas without further ado. What seems to be a much more difficult task is to predict and identify the threats in a precise manner and formulate a proactive security policy before the threats call in. The understanding of threats, perception of their dynamics and genuine evaluation contribute to an insightful proactive security policy. These factors come to decide what strategy is formulated, how the resources of deterrence, prevention, reaction, training and outcome management are distributed.

In the aftermath of the September 11 events in the United States, terrorism has taken control of the principal security strategy provisions, becoming one of the most important spheres of politics almost in all states of the world - at least in the countries of the so-called West -including those that have hardly ever suffered the influence of terrorism, have not had actually working terrorist organizations, have never carried a foreign policy that would have caused discontent among terrorists. Terrorism as a principal issue now has been put on the top of the agenda of all meetings that gather together heads of states, international organizations, political and economic forums. If we refer to the way the issue has established itself, almost every act of violence today is first of all assessed through the prism of terrorism.

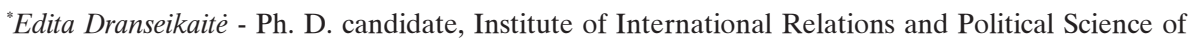
the University of Vilnius. Address: Vokiečiu 10, LT-2001 Vilnius, Lithuania, tel. +370-5-2514130, e-mail: edita@euro.lt 
It may seem paradoxical to some extent, but one would find it difficult to come across a similar term that would be more controversial in modern political discourse than terrorism. Until now, all attempts to reach an agreement on the universally accepted definition of terrorism ran into political and ideological deadlock.

Terrorism is scarcely a phenomenon to be called a new one in the world. However, the end of the Cold War and globalisation have created very favourable conditions for the development of terrorism as a new type of threat. The character, motivation, targets, strategy, tactics and logistics of terrorism have been under transformation ever since. It is not difficult to note that terrorism is becoming extremely popular in the globalisation age not only as an asymmetric means of fighting the stronger enemy of the "evil" countries of the world; the fight against terrorism is more and more often used as an internal and external policy instrument in Western democracies.

In this article the author analyses issues pertaining to the definition of terrorism, tendencies of the terrorist threat, the impact of globalisation on the terrorism phenomenon and opportunities and dangers behind the fight against terrorism in the globalisation age.

\section{Concept of terrorism: definition issues}

Terrorism is a concept that should be used with special care. To start with, such an assumption is based on the fact that terrorism is one of the few words that automatically raises panic and presses to take extreme actions. One author named terrorism as a "bomb-throwing" term.

The definition of terrorism is important both in political and social sciences. On the other hand, it would be difficult to find any other word that would be more controversial than terrorism in today's political discourse. Walter Laquer's "Age of Terrorism", the largest book on terrorism and its causes so far, aimed to portray what terrorism failed to be, indeed ${ }^{2}$. In the media and in the daily use the concept of terrorism has been used quite freely. The word "terrorism" was often used as a synonym that described phenomena such as political resistance, street riots, uprisings, partisan wars and many more. In terms of a scientific appeal the research of international terrorism as a phenomenon has remained complicated so far, given that there is still no adequate theoretical background available. ${ }^{3}$ None of the many definitions of terrorism has become universally accepted. In the most general sense, terrorism that is narrowly defined implies either the use of weapons of mass destruction, or a threat to use them. ${ }^{4}$ In this case, the definition would fail to incorporate the majority of the cases the world recognizes as terrorism (the September 11 events in the United States, for example). A broader definition, under supplementary circumstances, includes, among others, such phenomena like sabotage, arson, murder, various riots, etc.

\footnotetext{
${ }^{1}$ Maddocks M., "Terrorist - a Bomb-thrower of a Word”, The Christian Science Monitor, January $17,1980$.

${ }^{2}$ Laquer W., "The Age of Terrorism", Boston and Torronto: Little, Brown and Company, 1987.

${ }^{3}$ Staff B., "In Mideast one Weapon of Choice is a Loaded Word", The Christian Science Monitor, July $31,2001$.

${ }^{4}$ Holt M. P., "The Tricky Art of Defining “Terrorism”", The Christian Science Monitor, March 7, 2002.
} 
In this case, one must take into account various other factors to determine, whether one of these phenomena is terrorism or not (e.g. premeditated poisoning of drinkable water), whether it is a matter that the local police should deal with or not (eg., putting a house to fire for personal disagreements). Sometimes terrorism "masks" a partisan war (the difference is that terrorists either do not seek to take control over the territory or fail to keep it in their hands) or even an interstate war.

Terrorism has been mostly defined as a premeditated sub-state level activity or a threat directed against civil population that seeks political objectives - to ignite panic in the society, to put political protest against the state into action, to undermine or overthrow the political authority, to replace the current system of government. ${ }^{5}$ This definition includes three key elements characteristic of all definitions of contemporary terrorism: violence, private (civil) persons, and politics.

However, a long history of existence has lead terrorism to a large variety of appearances; today, the society faces a number of types of terrorism. As a result, there are many terrorisms and many more perceptions of what terrorism is that slow down the quest for a universally accepted definition. The understanding and evaluation of terrorism as a threat and as a phenomenon depends also on the country. The United Nations Organization has been in pursuit of a universally acceptable definition for 20 years, but so far all the efforts ended in failure. ${ }^{6}$

At the time when terrorism tendencies change and terrorism often loses the function of a political manifestation, accentuating the fear-raising and insecurity aspect, theoreticians of terrorism begin arguing if terrorism is a political activity or simply some type of a criminal undertaking (the $\mathrm{UN}$, as well as the majority of nation states). It is said that each terrorist act can largely be considered as a mere criminal offence, against civil population, aimed at generating psychological consequences instead of producing material losses. On the other hand, the opponents claim that the same definition implies that each criminal activity can be considered a terrorist act if we assume that its main objective is to stir up fear. ${ }^{7}$ Terrorism, however, is different in comparison to the majority of acts of criminal violence just because it is always rational. Rational in a sense that there is always an understanding of a link between the means used (violence) and the results expected (namely, the political objectives of terrorists). ${ }^{8}$

What needs to be said is that all efforts to provide a universal definition of terrorism depend on political and ideological issues. The concept of terrorism is a relative one and depends on how the party concerned defines it. In other words, what terrorism is and what it is not very often depends on who is the source of the evaluation: the victim or the person who commits violence. What one party considers a terrorist act, the other party may call a freedom fight or legitimate political resistance. Where does the dividing line between these groups lie? What factors decide what

\footnotetext{
${ }^{5}$ Laquer W., "Postmodern Terrorism", Foreign Affairs, September/October 1996

${ }^{6}$ Obote-Odora A., "Defining International Terrorism", E-Law-Murdoch University Electronic Journal of Law, Vol 6, No 1, March 1999, www.murdoch.edu.au, 0612 2001, p. 4.

${ }^{7}$ Obote-Odora A., (note 6), p. 20.

${ }^{8}$ Walker L.J., Schlagheck D. M., "The End-Game of Terror and Democratization: Implications for American Foreign Policy”, Wright State University, Dayton, Ohio, www.igc.org/intacad/cwl/terror3.html, 06082002.
} 
act of political violence is identified as terrorism, and what is not? Who is a "terrorist", and who is a "freedom fighter"? When does a "freedom fighter" become a "terrorist"? The Israeli-Palestinian conflict is one of such examples where attacks against civilians allow Israel to label its actions against the Palestinian autonomy as a war against terrorism rather than a fight of the two nations over the same piece of land. The Chechen war, in this sense, is an even "greyer zone": there is no doubt this fight is nothing but the fight of a nation for its independence, the actions and means of which, however, meet the definition of terrorism. Therefore, every attempt to define terrorism apart from the fight for national liberation and the implementation of the right for self-determination always raises the fear of the implication that in some cases terrorism is justified, i.e. to draw a borderline between the tolerable terrorism and non-tolerable terrorism.

According to Brian Simmons, what definition is provided depends also on who the target is and who the victims of the act of political violence are. What practice shows, however, is that if it is the US citizens that are victims of political violence, 80 per cent of the cases come to be named terrorist acts. In the meantime, in all other cases, only 50 per cent of the acts of violence are defined as terrorist activities. ${ }^{9}$ Thus, the definition of the act of violence as terrorism has first of all to do with judgement and evaluation. In this context the role of the United States Government is very important in defining terrorism and classifying whether the use of political violence is legitimate, or not. The US Governmental institutions, however, have failed to reach a consensus on the definition of terrorism that could be applied to and by each and all of them. Alali and Ekke offer six different definitions of terrorism the US Governmental institutions have articulated. According to these authors, such a mass of definitions and some flexibility that follows as a result have allowed the US Government to interpret terrorism "conveniently". As a consequence, the Government may classify one group or another, one state or another as a terrorist sponsoring group or state on the basis of how their ideological orientations fit those of the US. ${ }^{10}$ Yet, the critics of a value-based approach towards terrorism claim that the judgment whether an act of violence is terrorism or not should exclusively depend on the character of the act itself, not the identity of the perpetrator or the legitimacy of the causes. ${ }^{11}$

To sum up, efforts to define terrorism are first of all inevitably interlinked with political and ideological issues. Besides, terrorism is a very dynamic phenomenon. "The character of terrorism changed at the end of the last century giving birth to the majority of issues of definition and understanding" - one of the best known and indepth studies of terrorism claims. ${ }^{12}$ In the meantime, however, the majority of international organizations and states define threats in their security policies and strategies on the basis of the definitions of terrorism that reflect the situation characteristic of a number of decades of the last century. At the same time, they fail to embrace the magnitude of the current problem in the entire world.

\footnotetext{
${ }^{9}$ Simmons B. in Alali O., Eke K.K., "Terrorism, the News Media, and Democratic Political Order", www.igc.org/inctad/cwl/terror6.html, p. 3.

${ }^{10} \mathrm{Ibid}$, p. 3-4.

${ }^{11}$ Hoffman B. "Terrorism Trends and Prospects", in Countering the New Terrorism, RAND publications, 1999., p. 11.

${ }^{12}$ Laquer, (note 5), p. 21.
} 


\section{Dynamics of terrorism as a threat}

Contemporary terrorism is, for the most part, international terrorism. Almost every time it brings about international implications. Purely internal terrorism, traditional terrorism, rarely exists in practice. The reason is not only that the information on terrorist attacks crosses state borders. ${ }^{13}$ When Chechen fighters took several hundred civilians hostage in the Moscow theatre in October 2002, by definition this was clearly an internal terrorist act. However, there were a number of foreign citizens involved, international actors approached the fighters (foreign ambassadors, international organizations). Besides, President Putin came to put emphasis on the international character of this terrorist act, connections to $\mathrm{Al}$ Qaeda and the increased terrorist threat in the world. ${ }^{14}$

Moreover, terrorism increasingly becomes global. Terrorist groups appear to be able both to organize attacks everywhere in the world and to bring up consequences of a global impact. Indeed, the September 11 events in the United States showed that none of the countries of the world, independent of its political, geographic situation, size or power, cannot feel absolutely safe (economic consequences, spread of anthrax, insecurity and fear, etc.)

Terrorism becomes more and more fatal, that is, non-discriminating and lethal. During the last 25 years, according to statistics, the number of terrorist attacks in the world decreased (the international system and security realities as well as the attitude of the majority of states towards terrorism have changed, the majority of terrorist groups disappeared, the Soviet block, which was taken to be one of the most active sponsors of terrorism, collapsed). However, numbers of the fatalities these terrorist attacks have caused increased substantially. ${ }^{15}$ Such changes in terms of the tendencies of terrorism, in essence, reflect the result of several so-called "terrorist spectacles" - dramatic acts of violence that draw the attention of the whole world by causing heavy human casualties.

Traditional terrorism used to be of a discriminating character, directed at a precisely defined concrete group or persons (most frequently high-level political actors) and at avoiding civil human casualties. In the ninth decade, terrorism underwent significant changes - terror acts were more and more often carried out by suicides. Aimed to put fear in the society and destabilise the situation, terror acts were more and more often directed at civil population. However, even in this case terrorism was characterized by clear political objectives that made the attacks be planned so that the consequences (the number of victims, most often) they were giving birth to would draw the attention; on the other hand, they tried to avoid unduly "bloodiness" that could have caused negative reaction on the part of the society or unduly violence that could have reduced the number of supporters (IRA, Basques)..$^{16}$ However, recent terrorist attacks are for the major part projected in the way to cause as many civilian casualties as possible.

\footnotetext{
${ }^{13}$ Lebens Nacos B., "After the Cold War: Terrorism Looms Larger as a Weapon of Dissent and Warfare”, Columbia University, New York, www.igc.org/intacad/cwl/terror2.html, 06082002. ${ }_{14}$ CNN News, October 26, 2002.

15 "Countering the Changing Threat of International Terrorism", Report from the National Commission on Terrorism, Washington, 2000, p. 48. Also: Hoffman, (note 11), p. 10-12.

${ }^{16}$ Ibid. p. 6-7.
} 
Numbers of reasons bring about such a growth in terms of the "efficiency" and fatality of terrorism. First of all, there are certain models that let one assume that at least some terrorists are convinced that the attention is not earned that easy as it once used to be. Politics, the media, the society get accustomed to it, which makes them less sensitive to terrorist attacks. Therefore, the terrorists are brought up to situation where they feel obliged to organize more dramatic and more destructive attacks in order to reach the same effect they could have reached by less victimizing attacks earlier. ${ }^{17}$

Second, the means terrorists employ get increasingly modern. What makes guns and conventional explosives remain the most widely used weapons is the relative ease of buying them. At the same, time they become smaller, smarter, better fit to commit murder (e.g. nail bombs to kill as many victims as possible). Efforts to acquire (and use) chemical, biological or even nuclear weapons also become more frequent and persistent. The 1995 Tokyo metro attack is widely received as the beginning of chemical terrorism. The same apocalyptic group tried to spread the virus of anthrax in Japan, though, unsuccessfully. At the same time, after the September 11 events in the United States (the linkage is not proven), the virus of anthrax spread quite widely, causing a situation that triggered a crisis. Terrorist groups more often are trying to acquire weapons of mass destruction, nuclear weapons among them. As a result of globalisation and universal computerization, the threat of cybernetic terrorism is increasing: lots of scenarios have been designed that mould the potential of such kind of terrorist attacks. Casual, though real, crises verify that such scenarios have become real and possible to execute.

Terrorist groups seem unable to acquire the major part of modern weapons, first of all, chemical and nuclear weapons, unless they are helped by a state. Secret, though active, on the other hand, role of some of the states in support of terrorism is the third reason for this growing fatality. ${ }^{18}$ Five of the seven states the United Nations have identified as the sponsors of terrorism develop nuclear weapons under the aegis of respective nuclear programs, and later try to implement them. This includes the states the United States President George W. Bush addressed as the "axis of evil" in the new US security doctrine - Iraq, Iran, North Korea. State support reinforces the planning, reconnaissance, financial and logistical capabilities of ordinary terrorist groups. Besides, state-supported terrorist groups become less dependent on the support of the local community. Because of that they do not really care about the effect terrorist attacks are going to have on the public opinion. In spite of the fact that none of the world nations openly supports terrorism, Hoffman claims that some states are getting more and more keen on using terrorists as "surrogate fighters" - a secret, cheap force used for a secret war against more powerful enemies or for the sake of the annihilation of the neighbouring and inimical countries' regimes. ${ }^{19}$ To some extent

\footnotetext{
${ }^{17}$ Hoffman, (note 10), p. 13.

${ }^{18}$ See: Laquer, (note 5), p. 26-27, note 18, p. 8, 16-20., Quillen C., "State-sponsored WMD Terrorism: a Growing Threat", The Terrorism Research Center: Next Generation Terrorism Analysis, 2000, p. 26., Lesser I. O., "Changing Terrorism in a Changing World" in Countering the New Terrorism, RAND publications, 1999., p. 1-6.

${ }^{19}$ Hofman, (note 10), p. 15 .
} 
terrorism along with conventional war and favourable asymmetric strategy becomes a supplementary means, an alternative to direct confrontation with more powerful enemies, including the United States. ${ }^{20}$

The orientation of terrorism in the direction of the growing number of victims reflects one closely related development - the changing motivation of terrorists. Traditionally, terrorism grew on the left-wing ideologies. It gathered vitality on the removal of opponents for the sake of various concrete political objectives. Today, various religious extremist (Islamic fundamentalists) and post-apocalyptic groups, antiglobalistic movements have joined the ranks of the traditional ideological and ethnic/nationalistic terrorism. Reinforced by the hatred of the United States and overall Christian civilization, all this can be considered the basis for the increasing number of terrorist attacks. Motivation may be, and most often is, a mix of several factors. Religious terrorism, or the terrorism that is at least partly based on religious imperatives has made its contribution to the increasing fatality of terrorism. The statistics of terrorist acts show that terrorism that is based on religious motives is susceptible to higher fatality and non-discriminating killing over completely different value systems, mechanisms of legitimisation, morality perception, specific stance towards the world, even more than the secular terrorism. ${ }^{21}$ Usually, terrorism that is motivated by religious beliefs and hatred does not have concrete political objectives, except for a resolve to punish enemies (or everyone alien to one's religion or cult) by killing as much of them as possible, without much attention being paid on maintaining or drafting new disciples or sponsors by way of the attacks. ${ }^{22}$ Therefore, terrorism has been increasingly losing its key traditional element - to assume responsibility over the committed crimes and declare political requirements. Furthermore, major terrorist attacks - the spectacles - are known for the fact that the majority of the groupings accused of terrorism try to deny their association with the act immediately after. Such tendency of terrorism implies that for some groups violence becomes "an objective in itself rather than a means to reach the objectives devised". ${ }^{23}$

The character of terrorist groups themselves has transformed. The hierarchic structures and centralisation of the groups have grown weaker, too. Increasingly often the groups do act as separate units, bound together by relatively loose links and united by a common goal - most often universal hatred. Tracing one branch, cutting off the financial sources would not affect other branches. Such loose, decentralised transnational terrorist networks are hard to identify, watch and infiltrate into. ${ }^{24}$ Loosening of centralisation and control often means also fewer constraints on the selection of the operational targets, which, therefore, entails uncontrollable, usually more significant, human losses. Loosening structures of terrorist groups bring about more and more unprofessional terrorists or amateur terrorists who operate on the basis of either religious enmity, rage and hatred, or a different mix of motives that are often used by professional terrorists or states supporting terrorism for the sake of concea-

\footnotetext{
${ }^{20}$ Arquilla J., Ronfeldt D., Zanini M. "Networks, Netwar and Information Age Terrorism”, in Countering the New Terrorism, RAND publications, 1999, p. 38-54.

${ }^{21}$ Ibid, p. 20

${ }^{22}$ Note 15 , p. 7.

${ }^{23}$ Hoffman, (note 10), p. 28.

${ }^{24}$ Evans G., "Responding to Terrorism: Where Conflict Prevention and Resolution Fit in", Address at Johns Hopkins University (SAIS), October 9, 2001, p. 7.
} 
ling their involvement and avoiding the possible military response, or, as a result, diplomatic and economic sanctions. In general, terrorist groups become less dependent on states - states harbour and tolerate these groups; however, financing itself comes from different sources (oftentimes, the income off the illegal activities (drugs, weapons), nongovernmental organizations' funds, etc.) Because of this reason, it appears much more difficult to fight terrorism using conventional methods, such as economic sanctions.

In summary, terrorism is becoming a completely different kind of threat: the nature, motivation, targets, strategy, tactics and logistics of terrorism have been under transformation. Traditional terrorism still remains a major threat in some of the world regions. At the same time, however, the threat modern (new) international terrorism poses, is inevitably growing.

\section{Globalisation and terrorism}

After the Cold War, the family of threats expanded noticeably. This fact necessitated a wider security agenda, a need for new national and international security strategies; a need to look for new means of fighting against what comes up as a new threat. During the Cold War, national security in essence implied the defence of borders and territory against major threats of the bipolar world. Today, the majority of states, particularly in a better-developed part of the world face less acute military threats; bipolarity belongs to the past; this puts the onus on other threats. What seems to be true as well is the fact that other types of threats become more important irrespective of less acute military threats. Economic and social threats - these are the result of globalisation and increasing interdependence. Political threats are felt by those states that have retained either historically obsolete internal structures (autocratic monarchies or theocratic states), or fail to keep in step with the contemporary tendencies (communist states), or weak states - those states that fall short of implementing state functions. Everybody is aware of the environmental threats (global warming, shrinking ozone layer, and contamination of water resources). At the same time, though, only few have ever got to know what they are. Following the September 11 events, explosions in Indonesia, hostage crisis in Russia, everyone is aware of the danger terrorism poses. Moreover, terrorism turns into a permanent satellite and instrument the majority of these threats act by.

Globalisation is one of the factors affecting the new security situation in the world and the factor that explains the increasing strength of terrorist tendencies. First, globalisation has expanded the socio-economic basis of terrorism (social inequality, ethnic and religious discords, poverty and the problem of refugees, etc.). Activities of transnational corporations, growing economic integration, new fastdeveloping modern technologies, global communications and media expansion strengthen mutual interdependence and vulnerabilities.

For a long period of time, globalisation used to be treated as a source of peace, democracy, progress and rapid economic development of which the majority of the world countries and peoples would reap major benefits (integral globalisation) as a result. However, recent years have seen the consolidation of the positions of those who claim that the objective processes of globalisation (actively supported by transnational companies, financial and industrial communities, Western economic and 
political elite, and particularly, the United States), along with positive aspects carry with themselves the lethal consequences for the world civilization (detrimental globalisation). According to them, globalisation forms a bifurcated, divided, world..$^{25}$ It gives rise to conditions for developed and rich democracies to reach an even higher level of welfare and for less rich - to reach significant progress. In the meantime, as a result of the globalisation process the remaining part of the world creates conditions favourable to facilitate the enrichment of the limited political and economic elite. At the same time, the major part of the world population, unable to meet the information and modernization era, ruthless competition and abrupt changes, remains in poverty. Processes of globalisation raise a dilemma for 80 per cent of the world population who choose between "having lunch and being a lunch", according to an illustrative comparison of $\mathrm{P}$. Martin ${ }^{26}$. This is the main reason why various regions of the world view globalisation in their own way: there are plenty of people who have either suffered or believed they have suffered as a result. In this respect globalisation "gives a flush of anger" to those anti-Western regimes, ideologies, persons (including terrorists) who seek to punish Western democracies and everybody they blame for their failure. The Islamic world is the best example. This world sees itself lying in an extreme periphery of the West-dominated world - metropolis. At the same time, however, this world has managed to retain deeply felt and jealously cherished memories of the Islamic region as a cultural, economic and political centre (different to Africa or Latin America). That is why, according to A.Lieven, the attacks on the United States by Islamic terrorists in reality signify an attack not only on "the main patron of Israel" but also on the "main symbol of their own failure". ${ }^{27}$

Second, as a result of globalisation, increasing communication opportunities have created favourable conditions for the development, consolidation and geographic expansion of terrorism, making it easier for it to fulfil its core objective - publicity. In some regions of the world, new technologies have been used not only for the sake of people's welfare. They are somewhat more often used for the production of new weapons, establishment and expansion of international terrorist organizations. Distances seem to have lost relevance in the age of globalisation. Modern information systems and technologies enable terrorists to organize attacks in any place in the world, whereas remoteness from the geopolitical hotspots is no longer a guarantee of security. ${ }^{28}$

Third, globalisation has belittled the role of the state as the subject of international relations. It has lifted the weight of other subjects of international relations international organizations, transnational corporations and international formal and informal nongovernmental organizations, instead. In the period of global threats, the state is less and less able to defend its territory, protect private property, efficiently control information and welfare sources available to its population. M. Kennedy claims that this situation leads to the decline of the moral authority of the state. The

\footnotetext{
${ }^{25}$ Kugler R., "National Security in a Globalizing World of Chaos: The United States and European Responses", p. 42.

${ }^{26}$ Martin P. "The Global Trap: The Assault on Democracy and Prosperity", Moscow, 2001, p. 21.

${ }^{27}$ Lieven A. "The Roots of Terrorism, and a Strategy Against It", Prospect Magazine, Issue 68,

London: October 2001, p. 6.

${ }^{28}$ Kugler, (note 25), p. 37.
} 
declining authority of the state brings about less legitimacy to it. Its main reflection is the outstanding monopoly over power and violence. ${ }^{29}$ Such a situation is extremely auspicious for terrorist groups to use as they "capture" the right to use force and, as a result, lessen the state authority all the more.

In summary, the consequences of the globalisation process have become a fertile soil for the expansion of terrorism. It would be an exaggeration to say that globalisation is the direct cause of the events in the United States, Afghanistan or the Middle East. Their causes lie much deeper, indeed. Indirectly, however, globalisation has made its contribution to the problems of the contemporary world and the uncertainty over the future security. Globalisation not only kindles terrorism by means of escalating a conflict between the two worlds and separate society groups, but also provides some kind of a multiplication effect. Consequences of a terrorist act that come to pass are much larger because of the increased mutual interdependence and intensive communication. These consequences spread faster and reach a virtually unlimited audience.

\section{Fight against terrorism in the globalisation age: opportunities and dangers}

Globalisation and the end of the Cold War have created favourable conditions for terrorism to flourish. At the same time, they have given birth to a situation of mutual interdependence in the world when no country can feel safe, when no country can guarantee its security alone. Today, terrorism seems a completely different threat compared to the one it used to be in the ninth decade of the last century. It has been further evolving. Reality, however, demonstrates that it is possible to fight terrorism in an efficient way and preclude the prospects of it becoming a certainty. By the same token, conditions meant to fight terrorism have also naturally improved (better technical means; stronger cooperation among countries in this area; countries are less motivated to support terrorism; besides, the capacities of terrorist groups are very limited). On the other hand, what comes to mind is the fact that one might find it difficult to point to a successful case of fight against terrorism, whereas failures are really dramatic and obvious.

Two aspects seem important in fight against terrorism. First, the reduction of vulnerabilities stemming from possible terrorist attacks (border control, observation of suspected persons and groups, strengthening of security in potentially dangerous places (airports, metro), i.e. prevention. What limits the success of prevention is the so-called double asymmetry. First, terrorists have attained large advantage in this case: in order to be effective, defence must take account of all points of vulnerability around the world, while terrorists only have to target the weakest point to achieve success. Second, the costs of prevention are much higher compared to the costs of an attack. For example, to protect a single airport one has to spend millions, whereas a terrorist can carry out an attack causing thousands of human casualties with a single paper point.

\footnotetext{
${ }^{29}$ Kennedy M., "The 21st Century Conditions Likely to Inspire Terrorism”, in Kushner ed. The Future of Terrorism: Violence in the New Millenium, Sage, 1998, p. 190.
} 
Diminution of sources of the threats is the second aspect of the fight against terrorism. Economic sanctions, negotiations between the opposing parties, resolution of conflicts, removal of political discords (given that the origins of terrorism were virtually always clear, as are the political requirements) - these were the principal means of fighting traditional terrorism. Meanwhile, the sources and causes of contemporary, new terrorism do not seem that clear (globalisation, the US place in the world, national and ethnic conflicts, unequal distribution of global welfare, poverty and lack of education, religion and fanaticism). Such sources of threats are not subordinate to any separate country - this is an exclusive matter of the internationallevel security strategy.

International cooperation in the area of the fight against terrorism has been active so far. Until recently, however, it used to be limited due to some reasons, first of all, to a widely debated problem of consent over what acts of violence should be treated as terrorism, and what not. Devoid of consent over the object of fight, it is indeed even more difficult to agree upon the common strategy and means to achieve the devised objectives. The situation has transformed to some extent since after the September 11 events in the United States of America. What analysts of terrorism agreed upon was one thing - the world (at least the West) would have to reach an agreement over the singular definition and characteristics of terrorism as well as envisage means of a legitimate fight against it. The European Union became the first example of this. Only a few months had to pass before the Union member states reached a decision on the definition of terrorism, list of activities that were treated as terrorism, and joint means of fighting it. Besides, member states were entitled to take upon themselves national means to assure that terrorist attacks or attempts to organize them, participation in terrorist organizations, sponsorship of terrorist activities, etc. would be punished as such, not only as mere general criminal offences ${ }^{30}$. Moreover, until recently the majority of cooperation initiatives were based on the UN experience on what constituted terrorism, accumulated during the last decades of the last century. Therefore, they for the most part addressed traditional terrorism and failed to embrace new, oftentimes more dangerous, realities this phenomenon had given rise to.

The second problem of cooperation is related to the comparative importance every state delegates to the fight against terrorism in its national security strategy, driven by three main factors: (1) the threat terrorism causes to a particular state; (2) the ability of the state to fight terrorism on its own, devoid of the help of other states; (3) the comparative importance in the national security policy, if compared to other threats. ${ }^{31}$

In today's complex world there are numbers of various risks and dangers that, despite the fact that they can be dangerous for states, the population, economy, etc., do not necessarily develop into a real security threat. In other words, various risks, dangers, threats form the so-called threats scale. The position of one danger or anot-

\footnotetext{
${ }^{30}$ See: Ludlow P., "The Union's Action Following the Attacks in the USA on September 11th ", The Laeken Council, Brussels, 2002, p. 103-112.

31 "High-Impact Terrorism", Proceedings of a Russian-American Workshop, Moscow: The National Academy of Science, 2002, p. 59.
} 
her on the threats' scale, plus the outcome, i.e. when it becomes a threat, is decided by a number of factors: when leaders of states come to perceive some developments as threats (politics), when the society comes to perceive some developments as threats (surveys, public opinion - sociology) and when there is a high likelihood that some developments might take place (security and strategic studies). Following these criteria it becomes obvious that terrorism is a real threat to the United States. First, the statistics of terrorist acts in recent years show, beyond doubt, that the US security, interests, citizens and property are the main targets of terrorists. ${ }^{32}$ Terrorist activities are the main threat to the Israeli-Palestinian Peace process (also including the neighbouring Arab states) the United States has been promoting for 25 years now. Terrorism is a formidable threat to the stability of the US allies and US commitments in the world. Finally, terrorism is a threat to democracy and its expansion, given that the Governments that have suffered from a terrorist threat at one point or another become more susceptible to the increase of their security in exchange for the limitation of the openness of the society and civil rights. Thus, being the main target of the world terrorists, the United States has long begun to pay close attention to the fight against terrorism in its security strategy. In the meantime, the situation in Europe in terms of the comparative significance of the fight against terrorism and legal reglamentation of terrorism is a different one. In reality it depends on the extent the states were forced to confront terrorist activities in the past. As a result, in some EU countries terrorism had not made it into the list of main national security threats until recently; the fight against terrorism was not given exclusive reglamentation, whereas terrorist acts were treated and punished for as an ordinary breach of law. On the other hand, in some European countries, namely those where terrorism had become a major concern (France, Germany, Spain, Italy, Portugal, the United Kingdom) the fight against terrorism was given major prominence. These countries devised specific means and explicit sanctions to address it. ${ }^{33}$

The issue of the prominence of terrorism seems much more acute due to its nature prone to manifest itself (different to organized crime and weapons proliferation) by solitary dramatic violence "spectacles" calculated to catch the fancy of as much people as possible. Such spectacles temporarily highlight the profile of the terrorist threat until eventually the crisis subsides and is replaced with other threats. That is why the focus of many Governments (and their readiness to fight this threat) balances between complete ignorance and exaggerated attention. As soon as Governments concentrate on a terrorist threat like this, the pendulum swings to another extremity, usually at the expense of the attention being paid to other threats. ${ }^{34}$

Similarly, following the September 11 events in the United States, the threat of terrorism appeared in the first security strategies' paragraphs and amidst the most important policy areas in nearly all countries of the world (at least in the so-called West), independent of their previous terrorist experience, foreign policy and interests, and perceptions of the terrorist threat in the society.

\footnotetext{
${ }^{32}$ Hoffman, (note 10), p. 35.

${ }^{33}$ See: Commission of the European Communities, Proposal or a Council Framework Decision on Combating Terrorism, COM(2001) 521 final, Brussels, 19 September 2001.

${ }^{34}$ Pollard A. N., "The Next Presidents Terrorism Policy", Discussion Paper provided by The Terrorism Research Center, Inc., 2000.
} 
Why have terrorism and the fight against terrorism suddenly become the most important priority in the major part of the world? First of all it has gained prominence because of the increased terrorist threat, new terrorism tendencies and the increasing fatality and globalisation. The latter sanctioned the situation when the consequences of terrorist acts became a threat to the majority independent on who the primary target of the terrorists was, and who was not. The September 11 attacks of the symbols of the US economic might (the Twin Towers) and security (the Pentagon) were the biggest terrorist "spectacle". It seized heavier human losses than the IsraeliPalestinian conflict had seized in fifty years, pressing the majority of Governments to lift terrorism to the highest point on the threat scale momentarily.

On the other hand, terrorism becomes popular not only as a means of an asymmetric fight against a stronger enemy of the world's "evil" states. The fight against terrorism is often used as a foreign and internal policy instrument in West democracies. Without a common understanding on what terrorism is and what it is not the limits between terrorism and other violent activities become relative and extremely broad. To this we must add the changing nature of terrorism and the fact that it fails to keep its main feature - the assumption of responsibility and declaration of political requirements. There are, however, many reasons why governments turn prone to identify the so-called "grey zone" crimes, criminal and military activities as terrorism. First and foremost, this helps Governments, to some extent at least, justify their waning capabilities to perform the main function of the state - to ensure the security of the citizens and their property and make certain that these events never happen again, especially if they replicate and they are difficult to cope with. Along these lines, the responsibility for security is at least partly transferred into the international realm, as long as the root causes of terrorism go beyond the focus of the state security.

Second, terrorism is acknowledged as a new, specific threat. This means that special means are allowed and justified fighting it, thus it can become a powerful instrument in pursuance of foreign policy objectives and in defence of state interests. The prism of terrorism has been used for a long time already to define the Israeli-Palestinian conflict over the territory. Israel also exercised a pretext of a brawl against the Palestinian terrorism to make full use of all means, sometimes marginal, sometimes even contradicting the norms of the international law, in order to ensure its security and avoid an exceedingly negative reaction and discontent on the part of the international community. Russia has also been active in its efforts to disqualify the conflict in Chechnya as a "freedom fight". It has been trying to describe the conflict as "terrorism", and by these means allowing more freedom (and support) for its own military actions in the region. Finally, the military operations the US-led anti-terrorist coalition undertook in Afghanistan, deposition of the Taliban regime and the justification of pre-emptive strikes aimed at removing the Iraqi regime have become possible in the context of a broader, global fight against terrorism. Today, the fight against terrorism seems to be the only acceptable pretext for a military and economic intervention.

Third, some of the world's security experts claim that the end of the Cold War brought about a new element to the interests of the US and to the majority of other states' security politicians and experts, namely, to discover a new major "enemy" ${ }^{35}$

${ }^{35}$ Lieven A., (note 28), p. 2. 
Having in mind the fact that military threats have diminished in the majority of states, there emerged pressure over the allocation of means for the national defence and other, for the most part, social policies. In this sense "the worst-case scenario" and the elevation of a new threat become a powerful tool in seeking to draw the attention of Governments. It also helps create extremely strong positions in the fight over the distribution of resources. The elevation of the threat of terrorism and the prominence of the fight against terrorism has been given guarantees of the support of the public (provided it is thorny to either criticise the fight against terrorism or stand against the de-escalation of terrorist threats) not only in terms of increased financing, but also in terms of the establishment of the new specialised institutions or the consolidation of the powers of the existing institutions.

Besides, the external pressure to focus on terrorist threats and the fight against terrorism may be very strong in some countries. After the September 11 events, the first message President Bush delivered to the world was: "You are either with us, or you are with the terrorists. It is for you to decide. Those countries that choose unwisely, beware." ${ }^{36}$ The new US foreign policy doctrine, as a result, gave an important impetus for the majority of states to lift the fight against terrorism to the top of their national security agendas, independent of the real danger they faced.

Given their aspirations to join the Euro-Atlantic security organizations (the European Union and NATO), Central and East European countries have been facing a double pressure. It is expected that future member states will not become mere security consumers. Instead, it is expected that they are going to grant support for common goals, that they are going to adhere to shared policy courses and contribute to the strengthening of security in the region. For example, the new security strategy of Lithuania names terrorism as virtually the most important threat to Lithuania's security, despite the fact that in Lithuania's case the threat terrorism poses is not that obvious in comparison to that of the US. ${ }^{37}$ On the other hand, in the context of Lithuania's integration into the European Union, free movement of people and ensuring of the security of the EU's external borders, Lithuania is going to take on the responsibility over the European security. That is why the terrorist threat may increase.

Indeed, the September 11 events demonstrated that what presents a threat to some might craft opportunities for others. On the global level these events gave impetus to the formation of a unique, broader than ever, coalition against terrorism. These events have also raised hopes that the world bears in itself the potential to develop into a safer, better and more democratic entity than ever before. In the context of the global fight against terrorism, the United States got hold of the chance to implement their long-term foreign policy interests (i.e. strengthening the domination in Asia, the disarmament of Iraq). Otherwise their chances to implement the interests would have been less likely due to numerous factors: a stronger resistance on the part of the international community, the US internal policy stage and the public in the opposite case. As regards the European Union, the September 11 events happened to create an opportunity for the Union to strengthen its role as an international player and come up to a consensus over a number of initiatives aiming at strengthening common security and adding another impetus to the fight against terrorism. The

\footnotetext{
${ }^{36}$ Hirsh M., "Bush and the World", Foreign Affairs, September/October 2002.

${ }^{37}$ National Security Strategy, Lietuvos Respublikos Seimas: May 28, 2002. - Decree No. IX-907.
} 
situation meant that the European Union finally arrived at a position favourable to consolidate its two weakest pillars (Common Foreign and Security Policy and Cooperation in the Fields of Justice and Internal Matters). On the other hand, it also unveiled the division that existed among the EU member states on such issues as the definition of what the fight against terrorism was and the means to address it.

Russia is considered to be an absolute winner in this situation: its relations with the United States have improved significantly, the role Russia plays has also increased, Russia's involvement in the Euro-Atlantic structures (NATO and the EU) has become more substantial, Russia has been recognized to be a state with market economy (a number of experts claim this can be seen as an "acknowledgment" for Russia's support in the fight against terrorism and operations in Afghanistan), and it has also gained more freedom for its actions in Chechnya. For Central and East European countries, Lithuania among them, the terrorist attacks in the United States and their consequences have further strengthened their aspirations to join the transatlantic security space, NATO, and substantiated their readiness and ability to contribute to peacekeeping and peace enforcement along with other states of the world (deployment of troops in Afghanistan, permit to use the air space and airports, strengthening of the fight against terrorism, the establishment of the legal basis, etc.) Before September 11, 2001 only a few security analysts mentioned Romania and Bulgaria among the next NATO enlargement candidates. It became reality a year later.

Despite the globally increased terrorist threat, on the national security level some of the countries remain prone to overestimate the threat terrorism poses. In other words, they seem to be prone to "manufacture threats". This situation is exposed to several dangers, however. First of all, given that there are limited resources, overemphasizing the threat means greater attention is being paid to it at the expense of ignoring other threats or potential threats. Such a situation might eventually become dangerous in national security terms. Besides, too much attention being drawn to terrorism satisfies the main objective of terrorists - to strive for publicity and attention. To some extent this further motivates them to use terrorist strategies in the future. Second, the fight against terrorism and security warranties are usually sought for at the expense of state openness and civil freedoms. Following the September 11 events, the US Department of Justice detained more than 1,000 people. Until now, no charges have been tabled against the majority of them. ${ }^{38}$ A similar situation applies to Russia: in the aftermath of the hostage crisis in the Moscow theatre many people, Chechens by nationality, have been detained. No charges have been tabled against the majority of them either. What's more, as a result of an increased urgency of the terrorist threat, the majority of states, especially the US and the EU, severed immigration requirements for those who wanted to enter their territory, upgraded border controls, simplified the deportation regimes for foreigners and employed, among others, other control and limitation steps and economic sanctions. The European Union has for a long time been shaped into a space of freedom, security and justice. Now it is becoming "a Fortress Europe" instead. Restrictive means are justified when they become inevitable in order to ensure security. However, should they

\footnotetext{
${ }^{38}$ Public Agenda Special Edition: Terrorism, www.publicagenda.og/specials/terrorism/terror_over-
} view.htm, 14082002 . 
be too severe (especially in case of the overemphasised or the "artificial threats"), they might trigger a contrary effect, that is increase discontent and intolerance, divide the society or encourage marginal actions. The third problem (it is characteristic of any country, but particularly the United States) has to do with a tendency to overpersonalise the fight against terrorism - to search for a single terrorist, who embodies all evil. We have had Gadhafi, Abu Nidal, and now bin Laden..$^{39}$ One can note two dangers lying there. First, "the enemy" is created both in his own eyes, and in the eyes of his followers. Despite being paradoxical, it may make it easier to recruit new terrorists. Second, the personalisation of the fight against terrorism suggests that you only need to "deal with" a few persons in order to have the problem terrorism poses solved. Practice shows, however, that this is not the way to eliminate the problem; the problem evolves.

Cooperation among states in the fight against terrorism has also been hampered by the fact that positions of the states on the means of fighting against terrorism diverged. These developments seem to be contrary to what one could have expected after the September 11 events in the US and several subsequent terrorist attacks when the major part of the world (at least the Western one) came close to a common understanding on what terrorism was and agreed to give the fight against terrorism a major prominence on both national and international security agendas. Here we see a conflict of interests of the allies (the US and European states), the fact one could hardly have expected. Some of the states in Europe, first of all Germany, are in general against sanctions for Libya, Iran, Iraq and other states they have business relations with. These countries hold that the US interests cannot bring effect by means of permanent isolation of the "disobedient" regimes alone. On the other hand, lifting up the punitive means against the regimes that support terrorism amounts to making concessions and may bear negative consequences for the countries directly threatened by terrorists. As a result of the September 11 attacks, European countries expressed their absolute solidarity with the United States. They have supported and contributed to the military operations in Afghanistan carried out by the antiterrorist coalition and destined to remove the $\mathrm{Al}$ Qaeda network. The positions, however, diverged over the issue of the possibility to expand the geography of military operations further into the Middle East, namely Iraq. In the process of reaching a decision on how to solve the terrorist problem, falling short of an agreement over the legitimate means of retaliation against the terrorist attacks leads the states to a dilemma: "whether to employ non-democratic means to defend democracy, or not". ${ }^{40}$ The same dilemma applies to some states in Europe: the new strategy of the fight against terrorism, adopted by the United States, envisions the possibility of pre-emptive military strikes in order to avert threats posed by terrorism, nuclear weapons development, proliferation and deployment programs. Saddam Hussein's regime in Iraq should become the first target of the strategy. Critics cited this strategy as another example of America's "unilaterality", "imperialistic arrogance" and "enormous indifference" in terms of its stance toward the position of the allies. ${ }^{41}$ Notwithstanding

\footnotetext{
${ }^{39}$ Note 31 , p. 54

${ }^{40}$ Walker L.J., Schlagheck D. M., "The End-Game of Terror and Democratization: Implications for American Foreign Policy", Wright State University, Dayton, Ohio, p. 13.

${ }^{41}$ Krickus R.J., "JAV negali laukti, kol priešai persiauklès" ("US cannot wait until the enemies retrain"), Lietuvos rytas: Rytai-Vakarai, October 19, 2002.
} 
the fact that punitive actions and military operations may be inevitable in order to beat the threat of terrorism, there is always a danger that it could multiply instability in the region and trigger off the opposite result (although it has always been emphasised that the war against terrorism is not directed against Islam, that it is aimed against the terrorist organizations and states that sponsor terrorism, the majority of the Arab world identify the ever-expanding terrorist campaign as above all the anti-Islamic campaign). Besides, some of European states feel anxious about the possibility that the employment of such pre-emptive military strikes is going to create a new extremely dangerous precedent in international politics.

\section{Summary}

The national security policy of each and every state is aimed to address a number of likely, not necessarily catastrophic, threats - "the jungles of snakes" according to one of the former US Central Intelligence Agency directors. ${ }^{42}$ Such circumstances drive the security policy in different directions. They also weigh down such tasks as the identification of priorities and concentration on one specific low-level transnational threat or another, such as terrorism, organized crime, drug trafficking, etc. At the same time, however, the lack of consistency and focus limits the chances to understand, follow and adequately react to such complex threats like terrorism. It becomes even more difficult to focus one's attention and embark on adequate means to address the ambiguous and ever-changing threat. The new terrorism is entirely international or even global terrorism, fed on religious fundamentalism and hatred, oriented towards the largest possible number of human losses and leaving behind the main characteristic of terrorism - the claim of responsibility for the committed activities and declaration of political requirements.

The end of the Cold War and the consequences of the process of globalisation created favourable grounds for the expansion of such terrorism. After the September 11 events in the United States and as a result of later terrorist attacks, the image of detrimental globalisation has begun to establish itself in the world. The previous image of globalisation as the main source of peace and progress has been replaced by concerns over the potential cultural clash of civilizations or similar calamities in the future. By way of forming the international society on state and regional level, globalisation increases the socio-economic, ethnic, religious, cultural disunity of the society. This disunity favours such social interests that do not recognise the authority of the international system and state as well as activities of the terrorist groups that represent marginal social interests. Besides, the consequences of globalisation (expansion of communications, new technologies, etc.) lay down favourable conditions for these groups to act on the global level and multiply the effect terrorist attacks exert. In the age of globalisation terrorism becomes a popular means of asymmetric fight against a more powerful enemy. As such it negates the conventional military logic claiming that in order to be successful an attack requires three times as much capacity as the defence.

${ }^{42}$ Pollard A. N., (note 34). 
Globalisation is an irreversible process. Whether it is going to become a success or not will depend on the ability to protect oneself from negative consequences this phenomenon brings about. Today's terrorism is a new type of threat (this fact is recognized by all Western states). Therefore, a new type of means, new methods of fight and close cooperation between states must be devised to address it. Interstate cooperation is restrained by disagreements over the definition of terrorism and legitimate means of the fight against terrorism. It is also restrained by the fact that the fight against terrorism and terrorist threats is given varying values in the national security policy. In practice, some states are susceptible to overestimation of the terrorist threat. Various reasons, internal and external policy interests and external pressure, stand behind these actions. As a result, this situation creates a counterproductive effect by increasing security stakes. Besides, to some extent to due to the fact that until recently international terrorism was not defined universally as well as the failure to reach an agreement on the legitimate response to terrorist attacks, states often find themselves in a situation leading them to the violation of the norms of the international law, even for the sake of self-defence. These actions come to provoke discontent among both the states - targets of the imposed means and their own allies. Public opinion is also very sensitive to such developments. What's more, they stimulate a further expansion of terrorism.

Therefore, the main challenges that states face on their way to success in the fight against terrorism are to find an adequate balance between democratic freedoms and state security. States must fight terrorism, not a nation, religion or civilization. It must fight actions and behaviour, but not what one believes in. 